\title{
KAJIAN HUKUM USAHA BATIK GONGGONG SEBAGAI SERAGAM PEGAWAI NEGERI SIPIL KOTA TANJUNGPINANG
}

\author{
M. Endy Febri* \\ Kantor LO Kab. Lingga Tanjung Pinang
}

\begin{abstract}
The Tanjungpinang local government issued a Tanjungpinang Mayor Decree Number 37 of 2010 concerning the Official Uniform for Civil Servants and Non Civil Servants in Tanjungpinang Government Circle. The Decree states that Batik Gonggong is one of the official uniforms that must be worn. The Decree raises an issue of economical rights, consequently all the entrepreneurs should get the opportunity to compete others without any discrimination. The research concludes that public participation is needed to conduct a study in determining a batik pattern as the special characteristic of a place before the issuance of a decree of the local government. An open competition for the society or the related entrepreneurs should be opened because claiming a particular pattern may rise an economical consequence for public. The Tanjungpinang local government should give a transparent guarantee and the same rights of access on business information for every micro, small and middle entrepreneurs.
\end{abstract}

Keywords: Batik Gonggong, pattern, monopoly practices, Tanjungpinang City.

\begin{abstract}
Abstrak
Pemerintah Kota Tanjungpinang menerbitkan Peraturan Walikota Tanjungpinang Nomor 37 Tahun 2010 tentang Pakaian Dinas Pegawai Negeri Sipil dan Non Pegawai Negeri Sipil Di Lingkungan Pemerintah Kota Tanjungpinang. Peraturan tersebut menyatakan bahwa Batik Gonggong sebagai salah satu pakaian dinas yang wajib digunakan. Penetapan tersebut menimbulkan hak ekonomi sehingga seyogyanya semua pelaku usaha berhak mendapatkan kesempatan yang sama untuk bersaing, agar tidak terjadi diskriminasi. Penelitian ini menyimpulkan bahwa diperlukan keterlibatan publik untuk membuat kajian dalam menentukan suatu motif batik untuk dijadikan produk khas daerah, sebelum menjadi produk hukum pemerintah daerah. Sayembara terbuka untuk masyarakat atau pelaku usaha terkait harus diadakan karena kegiatan tersebut menimbulkan konsekuensi ekonomi terhadap publik. Pemerintah Kota Tanjungpinang sebaiknya memberikan jaminan transparansi dan akses yang sama bagi semua pelaku usaha mikro, kecil, dan menengah atas segala informasi usaha.
\end{abstract}

Kata Kunci: Motif Batik Gonggong, Praktik Monopoli, Kota Tanjungpinang

*Alamat Korespondensi : endyfebri@gmail.com

JOURNAL OF LAW AND POLICY TRANSFORMATION 


\section{A. Latar Belakang Masalah}

Karya seni yang dikemas dan berpijak dari tema kearifan lokal suatu daerah dapat menghasilkan manfaat ekonomi. Manfaat ini memberikan dampak yang sangat luas terhadap produk tersebut, baik sebagai sebuah karya maupun sebagai komoditas bernilai ekonomi, yang pada muaranya, kreatifitas tersebut akan menjadi bagian dari usaha memperkaya khazanah kebudayaan bangsa. Batik salah satu contohnya. Seni Batik adalah satu dari sekian banyak karya seni bangsa Indonesia yang sudah mendunia.

Definisi batik berdasarkan Ensiklopedi Nasional Indonesia adalah suatu seni tradisional asli Indonesia dalam menghias kain dan bahan lain dengan motif hiasan dan pewarna khusus. Definisi batik menurut terminologinya adalah gambar yang dihasilkan dengan menggunakan alat canting atau sejenisnya dengan bahan lilin sebagai penahan masuknya warna. ${ }^{1}$ Menurut Iwan Tirta, batik merupakan teknik menghias kain atau tekstil dengan menggunakan lilin dalam proses pencelupan warna, di mana semua proses tersebut menggunakan tangan.

Batik Gonggong merupakan motif batik dari Tanjungpinang, Provinsi Kepulauan Riau. Batik yang bermotif Gonggong (latin: Strombus Turturella), sejenis kerang cangkang keras berwarna cerah yang banyak ditemukan di laut Tanjungpinang dan seputar wilayah Kepulauan Riau, telah menjadi daya tarik sendiri bagi warga dan Pemerintah Kota Tanjungpinang.

Motif Batik Gonggong merupakan motif batik pertama yang diperkenalkan dari Kota Tanjungpinang. Ide menciptakan motif batik khas daerah selalu berkaitan dengan simbol atau elemen khusus yang sangat mengingatkan orang kepada daerah tersebut.

Dari hasil penelitian, banyak pemerintah kota/kabupaten di Provinsi Kepulauan Riau mendukung dan memberi apresiasi terhadap geliat usaha masyarakat dibidang ini, khususnya terhadap motif - motif batik tradisi atau motif - motif yang dapat mengangkat nama daerah asalnya, termasuk Pemerintah Kota Tanjungpinang.

Tahun 2010 Pemerintah Kota Tanjungpinang menerbitkan Peraturan Walikota (Perwako) Tanjungpinang Nomor 37 Tahun 2010 tentang Pakaian Dinas Pegawai Negeri Sipil dan Non Pegawai Negeri Sipil Di Lingkungan Pemerintah Kota Tanjungpinang. Dimana pada Lampiran II Peraturan Walikota tersebut menyatakan bahwa Batik Gonggong sebagai salah satu pakaian dinas yang wajib digunakan.

Dalam Peraturan Walikota Tanjungpinang Nomor 37 Tahun 2010 tersebut, ditegaskan dalam Lampiran II bahwa Batik Gonggong bagi semua PNS dan Non PNS Pemerintah Kota Tanjungpinang digunakan pada Hari Rabu, tiap minggu pertama dan minggu ketiga setiap bulannya.

Pemerintah Kota Tanjungpinang secara jelas telah mencantumkan nama motif batik dalam peraturan tersebut, dimana motif batik itu berkaitan erat dengan pencipta motif dan hasil karyanya.

${ }^{1}$ Suyanto, A. N., 2002, Sejarah Batik Yogyakarta, Merapi, Yogyakarta, hlm. 2. 
Pencipta motif dan hasil karya terkait erat dengan dunia ekonomi atau dunia usaha. Terdapat dua pendekatan yang digunakan dalam hukum persaingan usaha. Pendekatan per se illegal dan rule of reason adalah konsep klasik dalam hukum persaingan usaha. Kedua pendekatan ini juga berlaku pada Undang-Undang Nomor 5 Tahun 1999, sehingga ada bentuk perjanjian atau kegiatan yang per se, namun ada juga bentuk perjanjian atau kegiatan yang rule of reason. ${ }^{2}$

Secara sederhana, kedua pendekatan itu 'seperti' delik formal dan delik material. Pada delik formal, unsur-unsur pidananya sudah dianggap lengkap begitu perbuatannya itu selesai dilakukan, sehingga tidak perlu ada pembuktian lebih lanjut. Pada delik material, unsur-unsur itu belum lengkap jika syarat akibat perbuatan itu tidak tercakup di dalamnya. Contohnya, tindak pidana pembunuhan (Pasal 338 KUHP) adalah contoh jenis delik material karena akibatnya harus berupa kehilangan nyawa terlebih dahulu. Apabila belum ada korban meninggal, belum dapat disebut pembunuhan.

Pada hakikatnya, semua tindakan yang terlarang secara per se diasumsikan mengandung konsekuensi yang lebih berat dibandingkan dengan rule of reason. Misalnya, Pasal 5 ayat (1) tentang perjanjian penetapan harga: "Pelaku usaha dilarang membuat perjanjian dengan pelaku usaha pesaingnya untuk menetapkan harga atas suatu barang dan atau jasa yang harus dibayar oleh konsumen atau pelanggan pada pasar bersangkutan yang sama. " Pasal ini dimasukkan dalam kategori terlarang secara per se.

\section{B. Perumusan Masalah}

Dari latar belakang yang telah diuraikan, maka peneliti menemukan permasalahan:

1. Bagaimana kaitan hukum persaingan usaha Batik Gonggong sebagai bagian dari pakaian dinas yang wajib dikenakan oleh Pegawai Negeri Sipil dan Non Pegawai Negeri Sipil Di Lingkungan Pemerintah Kota Tanjungpinang dihubungkanUndang-Undang Nomor 5 Tahun 1999 tentang Larangan Praktik Monopoli dan Persaingan Usaha Tidak Sehat dan Undang-Undang Nomor 20 Tahun 2008 tentang UMKM ?

2. Bagaimana kesetaraan hak pelaku usaha sejenis dengan dikeluarkannya Peraturan Walikota Tanjungpinang Nomor 37 Tahun 2010 tentang Pakaian Dinas Pegawai Negeri Sipil dan Non Pegawai Negeri Sipil Di Lingkungan Pemerintah Kota Tanjungpinang ?

3. Bagaimana solusi atau saran kepada Pemerintah Kota Tanjungpinang menentukan langkah untuk menetapkan motif batik atau produk dari pelaku usaha menjadi produk atau motif batik khas daerah yang wajib digunakan di lingkungan Pemerintah Kota Tanjungpinang tanpa menimbulkan permasalahan hukum? 


\section{Metode Penelitian}

Penelitian ini adalah penelitian hukum normatif yang bersifat deskriptif kualitatif. Penelitian ilmu hukum normatif adalah pengkajian terhadap bahan-bahan hukum, baik bahan hukum primer maupun bahan hukum sekunder.

Adakalanya untuk menentukan isu hukum diperlukan informasi yang bersifat umum, informasi ini dimaksudkan agar dapat membantu memberi orientasi terhadap masalah yang diteliti. Jika seorang peneliti menghadapi situasi yang demikian ini, jalan terbaik yang harus dilakukan adalah diperlukan penelahaan terhadap bahan hukum sekunder, melalui bantuan bahan hukum sekunder tersebut isu hukum dapat dirumuskan dengan tajam.

Pendekatan deskriptif kualitatif bertujuan untuk menggambarkan, meringkaskan berbagai kondisi atau berbagai fenomena realitas sosial yang ada di masyarakat yang menjadi objek penelitian dan berupaya menarik realitas tersebut kepermukaan sebagai suatu karakter, model, tanda atau gambaran tentang situasi, kondisi atau fenomena tertentu.

Data yang digunakan dalam penelitian ini adalah data sekunder dan data primer sebagai pendukung data sekunder. Data sekunder yang digunakan dalam penelitian ini sebagai berikut:

1. Bahan hukum primer berupa:

1.1 Undang-Undang Dasar Negara Republik Indonesia Tahun 1945

1.2 Undang-Undang Nomor 5 Tahun 1999 tentang Larangan Praktik Monopoli dan Persaingan Usaha Tidak Sehat

1.3 Undang-Undang Nomor 28 Tahun 1999 tentang Penyelenggaraan Negara yang Bersih dan Bebas Kolusi, Korupsi dan Nepotisme (KKN)

1.4 Undang-Undang Nomor 12 Tahun 2011 Tentang Pembentukan Peraturan Perundang-undangan

1.5 Undang-Undang Nomor 19 Tahun 2002 tentang Hak Cipta

1.6 Undang-Undang Nomor 20 Tahun 2008 tentang Usaha Mikro, Kecil dan Menengah

1.7 Undang-Undang Nomor 28 Tahun 2014 tentang Hak Cipta

1.8 Undang-Undang Nomor 23 Tahun 2014 tentang Pemerintahan Daerah

1.9 Peraturan Walikota Nomor 37 Tahun 2010 Tentang Pakaian Dinas Pegawai Negeri Sipil dan Non Pegawai Negeri Sipil Di Lingkungan Pemerintah Kota Tanjungpinang

1.10 Peraturan Walikota Tanjungpinang Nomor 13 Tahun 2012 tentang Perubahan atas Peraturan Walikota Nomor 37 Tahun 2010 Tentang Pakaian Dinas Pegawai Negeri Sipil dan Non Pegawai Negeri Sipil Di Lingkungan Pemerintah Kota Tanjungpinang

1.11 Peraturan Walikota Tanjungpinang Nomor 6 Tahun 2013 tentang Pakaian Dinas Pegawai Negeri Sipil dan Non Pegawai Negeri Sipil Di Lingkungan Pemerintah Kota Tanjungpinang

2. Bahan hukum sekunder merupakan penjelasan mengenai bahan hukum primer, penelurusan dokumen-dokumen, buku-buku, hasil-hasil penelitian dan literatur lainnya yang relevan dengan permasalahan yang dibahas.

3. Bahan hukum tersier berupa Kamus Besar Bahasa Indonesia. 
Selain data sekunder, data primer digunakan sebagai pendukung data sekunder, dimana obyek penelitian diadakan pada:

a) Para Pegawai Negeri Sipil dan Non Pegawai Negeri Sipil di Bagian Kesra Sekretariat Daerah Kota Tanjungpinang yang menjalani kebijakan Peraturan Walikota Tanjungpinang Nomor 37 Tahun 2010

b) Mantan karyawan Butik Selaras, butik tempat penjualan resmi Batik Gonggong di Tanjungpinang

c) Anggota Dewan Kerajinan Nasional Daerah (Dekranasda) Kota Tanjungpinang

d) Konsumen Batik Gonggong

Sumber data dalam penelitian ini adalah tulisan atau dokumen-dokumen yang terkait langsung dengan penelitian yang diperoleh melalui studi kepustakaan dan dokumen (library research).

Penelitian ini menggunakan metode analisis data secara kualitatif. Dalam penelitian kualitatif, teori lebih diartikan sebagai teori pola, yaitu tidak menekankan pemikiran deduktif logis (teori sebab akibat) dan mengandung serangkaian konsep dan hubungan yang saling terkait tetapi tidak mengharuskan pernyataan sebab akibat.

Metode analisis data secara kualitatif juga berarti membentuk sebuah sistem yang rapat dan saling memperkuat yang terdiri dari konsep-konsep yang dapat saling menjelaskan lalu menentukan urutan tahapan atau bagian sehingga menjadi sistem ide yang memberi informasi dengan teori atau pola tertentu dalam sebuah penelitian.

\section{Hasil Penelitian Dan Pembahasan}

Dalam melakukan kajian hukum ini, kerangka landasan yuridis yang digunakan sebagai dasar telaah dalam penelitian adalah:

1. Undang-Undang Dasar Negara Republik Indonesia Tahun 1945

2. Undang-Undang Nomor 5 Tahun 1999 tentang Larangan Praktik Monopoli dan Persaingan Usaha Tidak Sehat

3. Undang-Undang Nomor 28 Tahun 1999 tentang Penyelenggaraan Negara yang Bersih dan Bebas Kolusi, Korupsi dan Nepotisme (KKN)

4. Undang-Undang Nomor 19 Tahun 2002 dan Undang-Undang Nomor 28 Tahun 2014 tentang Hak Cipta

5. Undang-Undang Nomor 20 Tahun 2008 tentang Usaha Mikro, Kecil dan Menengah

6. Undang-Undang Nomor 12 Tahun 2011 Tentang Pembentukan Peraturan Perundang-undangan

7. Undang-Undang Nomor 23 Tahun 2014 Tentang Pemerintahan Daerah

8. Peraturan Walikota Tanjungpinang Nomor 37 Tahun 2010 tentang Pakaian Dinas Pegawai Negeri Sipil dan Non Pegawai Negeri Sipil Di Lingkungan Pemerintah Kota Tanjungpinang

9. Peraturan Walikota Tanjungpinang Nomor 13 Tahun 2012 tentang Perubahan atas Peraturan Walikota Nomor 37 Tahun 2010 Tentang Pakaian Dinas 
Pegawai Negeri Sipil dan Non Pegawai Negeri Sipil Di Lingkungan Pemerintah Kota Tanjungpinang

10. Peraturan Walikota Tanjungpinang Nomor 6 Tahun 2013 tentang Pakaian Dinas Pegawai Negeri Sipil dan Non Pegawai Negeri Sipil Di Lingkungan Pemerintah Kota Tanjungpinang

Penelitian ini menggunakan Teori Hukum Integratif dari Profesor Romli Atmasasmita sebagai pijakan. Teori ini merupakan perpaduan antara teori hukum pembangunan dan teori hukum progresif, dengan memandang hukum sebagai sistem nilai (system of values), selain hukum merupakan sistem norma (system of norms) sebagaimana dikemukakan Profesor Mochtar Kusumaatmaja dalam teori hukum pembangunan dan hukum sebagai sistem perilaku (system of behavior) sebagaimana dikemukakan oleh Profesor Satjipto Rahardjo dalam teori hukum progresif.

Ketiga hakikat hukum itulah yang disebut oleh Romli Atmasasmita sebagai tripartite character of the Indonesian legal theory of social and bereucratic engineering, yaitu rekayasa birokrasi dan rekayasa masyarakat yang dilandaskan pada sistem norma, sistem perilaku, dan sistem nilai yang bersumber pada Pancasila sebagai ideologi bangsa Indonesia. Pandangan inilah yang secara utuh terangkum dikenal sebagai Teori Hukum Integratif.

Masih kurangnya upaya untuk menemukan pemikiran hukum khas Indonesia membuat bangsa Indonesia kerap dengan serta-merta mengadopsi mentah dan utuh pemikiran hukum barat yang belum tentu dapat diterima oleh masyarakat atau budaya timur. Dari itu, muncul pandangan Romli Atmasasmita untuk menelurkan sebuah teori baru yang disebut Teori Hukum Integratif. ${ }^{3}$

Hukum Integratif menggali nilai filsufis Pancasila sebagai akar atau dasar terbentuknya hukum. Hukum Integratif mengemukakan bahwa, melalui kinerja BSE (Social and Beaureucratic Enginering) setiap langkah pemerintah dalam pembentukan hukum dan penegakan hukum merupakan kebijakan berlandaskan sistem norma dan logika berupa asas dan kaidah dan kekuatan normatif dari hukum harus dapat diwujudkan dalam perubahan perilaku masyarakat dan birokrasi ke arah cita-cita membangun negara hukum yang demokratis. Negara hukum demokratis itu digali dari tiga pilar, yaitu penegakan berdasarkan hukum (rule by law), perlindungan Hak Azazi Manusia (enforcement of human right) dan akses masyarakat untuk memperoleh keadilan (acces to justice).

Nilai yang dimaksud didalam Hukum Integratif adalah Pancasila sebagai nilai tertinggi untuk melakukan perubahan terhadap sistem norma dan sistem perilaku yang berkeadilan sosial. Hukum integratif merepresentasikan hukum adalah Pancasila. Seperti pernyataan dalam stufenbaut theory dari Hans Kelsen yang menggambarkan bahwa dalam teori piramida, harus ada norma dasar dalam setiap pembentukan peraturan perundang-undangan.

Hukum integratif adalah teori hukum yang memandang, hukum hari ini (menurut pandangan teori hukum pembangunan) bisa berubah esok, karena perilaku warga masyarakat (menurut pandangan teori hukum progresif) yang begitu

${ }^{3}$ http://luthfiwe. blogspot. com/2012/06/integrasi-teori-hukum-pembangunan-dan. Html, diakses tanggal 5 Desember 2014 
dinamis, namun dalam pembentukan hukum yang baru berdasarkan hukum yang responsif (menurut pemikiran Nonet dan Zelznik), tidak dapat dilepaskan dari akarakar budaya atau ciri khas bangsa Indonesia yang telah tersublimasi dalam Pancasila. $^{4}$

Karena teori hukum integratif merupakan perpaduan dari teori hukum pembanguan dan teori hukum progresif, berikut peneliti paparkan beberapa hal terkait teori hukum ini.

Ada beberapa argumentasi mengapa teori hukum pembangunan banyak mengundang banyak atensi atau perhatian, yang apabila dijabarkan aspek tersebut secara global adalah sebagai berikut: Pertama, Teori Hukum Pembangunan merupakan teori hukum yang diciptakan oleh orang Indonesia dengan melihat dimensi dan kultur masyarakat Indonesia. Oleh karena itu, dengan tolok ukur dimensi teori hukum yang tumbuh dan berkembang sesuai dengan kondisi Indonesia, maka hakikatnya apabila diterapkan akan sesuai dengan kondisi dan situasi masyarakat Indonesia yang pluralistik.

Kedua, secara dimensional maka teori hukum pembangunan memakai kerangka acuan pada pandangan hidup (way of life) masyarakat serta bangsa Indonesia berdasarkan asas Pancasila yang bersifat kekeluargaan maka terhadap norma, asas, lembaga dan kaidah yang terdapat dalam teori hukum pembangunan tersebut relatif sudah merupakan dimensi yang meliputi structure (struktur), culture (kultur) dan substance (substansi) sebagaimana dikatakan oleh Lawrence W. Friedman. ${ }^{5}$

Ketiga, pada dasarnya teori hukum pembangunan memberikan dasar fungsi hukum sebagai "sarana pembaharuan masyarakat"6 (law as a tool social engeneering) dan hukum sebagai suatu sistem sangat diperlukan bagi bangsa Indonesia sebagai negara yang sedang berkembang.

Progresif juga berarti teori hukum yang menerapkan hukum tidak boleh kaku, menolak status quo dan mengedepankan kepastian hukum dengan bertolak dari kepentingan manusia itu sendiri. Hukum sangat berperan dalam pembangunan. Menurut Roscoe pound, hukum merupakan suatu alat perekayasa sosial (tool of social engineering). ${ }^{7} \mathrm{Hal}$ ini berarti hukum bisa berfungsi untuk mengendalikan masyarakat dan bisa juga menjadi sarana untuk melakukan perubahan-perubahan masyarakat. $^{8}$

\footnotetext{
${ }^{4} \mathrm{http} / /$ www.negarahukum.com/hukum/mengurai-sepintas-\%E2\%80\%9Chukum integratif\%E2\%80\%9D-romli-atmasasmita. Html, diakses tanggal 5 Desember 2014

${ }^{5}$ Lawrence W. Friedman, American Law : An invaluable guide to the many of the law, and how it affects our daily lives, W. W Norton \& Company, New York, 1984, hlm. 1-8. Dan pada legal culture and social development, stanford law review, New York, hlm 1002-1010 serta dalam law in America: a Short History, Modern Library Chronicles Book, New York, 2002, hlm. 4-7.

${ }^{6}$ Romli Atmasamita, "Menata kembali masa depan pembangunan hukum nasional", Makalah disampaikan dalam Seminar Pembangunan Hukum Nasional VIII di Denpasar, 14-18 Juli 2003, hlm. 7

${ }^{7}$ Lili Rasyidi, 1990, Dasar-Dasar Filsafat Hukum, Citra Aditya, Bandung, hlm. 47.

${ }^{8}$ Satjipto Rahardjo, 2010, Ilmu Hukum, Citra Aditya Bakti, Bandung, hlm. 189.
} 
Menurut Profesor Romli, secara teoritis teori hukum pembangunan dan teori hukum progresif cenderung berdasarkan pada teori hukum yang sama, yaitu sociological jurisprudence dari Roscoe Pound dan pragmatic legal realism dari Eugen Ehrlich. Namun, teori hukum progresif lebih diperkuat oleh pengaruh aliran studi hukum kritis (critical legal studies).

Geliat kreativitas masyarakat untuk mengembangkan budaya lokal harus didukung oleh pemerintah daerah. Bantuan dapat berupa melahirkan produk hukum daerah yang pro terhadap usaha - usaha terkait serta mendorong tumbuh - kembang iklim yang kondusif untuk pengembangan produk - produk kerajinan khas daerah. Memiliki payung hukum yang jelas dan kesempatan yang setara bagi semua pihak yang memiliki niat dan kemampuan dalam bidang tersebut.

Terkait dengan penelitian ini, secara penegakan atau penindakan hukum, tidak terjadi pelanggaran hukum secara pidana maupun perdata dalam kajian hukum Batik Gonggong ini. Tetapi, ditemukan bahwa hak untuk mendapatkan informasi usaha bagi sektor usaha mikro, kecil, menengah atau masyarakat dan pelaku usaha sejenis untuk bermitra dengan pemerintah daerah, belum terakomodir secara adil dan setara.

Akses pihak lain diluar pelaku usaha (Batik Gonggong) untuk mendapatkan keadilan dan kesetaraan dalam informasi yang terkandung nilai ekonomis untuk pengembangan dan pemberdayaan usaha masyarakat belum tersampaikan dengan baik.

Untuk melakukan perubahan menuju sistem norma dan sistem perilaku masyarakat serta birokrat yang berkeadilan sosial, seluruh kebijakan atau produk hukum pemerintah dan pemerintah daerah harus mengaktualisasikan keadilan sosial. Termasuk keadilan yang mengatur ekonomi masyarakat didalamnya.

Nilai dasar dalam hukum integratif adalah Pancasila, sebagai nilai tertinggi untuk melakukan perubahan terhadap sistem norma dan sistem perilaku yang berkeadilan sosial. Hukum integratif adalah teori hukum yang memandang, hukum hari ini (menurut pandangan teori hukum pembangunan) bisa berubah esok, karena perilaku warga masyarakat (menurut pandangan teori hukum progresif) yang begitu dinamis, namun dalam pembentukan hukum yang baru berdasarkan hukum yang responsif (menurut pemikiran Nonet dan Zelznik), tidak dapat dilepaskan dari akarakar budaya atau ciri khas bangsa indonesia yang telah tersublimasi dalam Pancasila.

Walaupun peraturan perundang-undangan dapat terus berubah, tetapi asas keadilan sosial yang diamanatkan Pancasila tidak boleh disingkirkan, termasuk keadilan ekonomi didalamnya. Peraturan Walikota Tanjungpinang Nomor 37 Tahun 2010 tentang Pakaian Dinas Pegawai Negeri Sipil dan Non Pegawai Negeri Sipil Di Lingkungan Pemerintah Kota Tanjungpinang 'terkesan' seperti mengarahkan kepada penggunaan suatu produk tertentu. Undang-Undang Nomor 5 Tahun 1999 tentang Larangan Paraktik Monopoli dan Persaingan Usaha Tidak Sehat Pasal 19 menyatakan:

Pelaku usaha dilarang melakukan satu atau beberapa kegiatan, baik sendiri maupun bersama pelaku usaha lain, yang dapat mengakibatkan terjadinya praktik monopoli dan atau persaingan usaha tidak sehat berupa : 
1. Menolak dan atau menghalangi pelaku usaha tertentu untuk melakukan kegiatan usaha yang sama pada pasar bersangkutan.

2. Atau mematikan usaha pesaingnya dipasar bersangkutan sehingga dapat mengakibatkan terjadinya praktik monopoli dan atau persaingan usaha tidak sehat.

Penjelasan Undang - Undang tersebut diatas, berlaku untuk skala nasional, untuk range minimal $50 \%$ pasar nasional. Dalam kajian hukum Batik Gonggong ini, pelaku usaha Batik Gonggong tidak termasuk dalam kategori Pasal ini. Sebab, Batik Gonggong ruang lingkup usahanya baru terkonsentrasi di Provinsi Kepulauan Riau umumnya, Kota Tanjungpinang dan seluruh pegawai Pemerintah Kota Tanjungpinang pada khususnya.

Pendekatan hukum rule of reason dalam larangan praktik monopoli dan persaingan usaha tidak sehat, mencakup niat atau perilaku daripada pelaku usaha. Walau tak terjadi sanksi atau penetapan pelanggaran hukum, perbuatan yang tidak merepresentasikan proses keadilan ekonomi untuk seluruh kalangan usaha mikro, kecil dan menengah harus dibenahi dan diperbaiki metode atau sistemnya.

Untuk mewujudkan masyarakat daerah yang adil dan makmur, prinsip keadilan harus dijalankan oleh pemerintah daerah. Perlakuan adil artinya, peraturan atau keputusan kepala daerah harus berlaku rata dan sama untuk masyarakat di wilayahnya. Tak jarang, konsekuensi dari keadilan dengan memberi ruang kepada banyak orang untuk turut berpartisipasi, turut mengeluarkan ide atau pendapat warga agar mendapatkan keputusan terbaik, sebelum pemerintah daerah melahirkan sebuah peraturan atau keputusan.

Keterkaitannya dengan Batik Gonggong adalah, diperlukan keterwakilan atau keterlibatan publik yang memahami mengenai produk atau seni khas daerah untuk membuat kajian dalam menentukan suatu motif batik untuk dijadikan produk khas daerah, sebelum menjadi kebijakan atau produk hukum pemerintah daerah. Walaupun dalam Standar Operasional pembuatan Peraturan Walikota Tanjungpinang tidak mencantumkan harus adanya keterlibatan masyarakat, idealnya proses pembuatan produk hukum daerah yang dapat menimbulkan peluang pemberdayaan untuk seluruh pelaku usaha di Tanjungpinang, disosialisasikan atau digelar sayembara terbuka untuk masyarakat atau pelaku - pelaku usaha terkait, agar hak atas konsekuensi ekonomi yang timbul dinikmati pelaku usaha atas asas keadilan.

Pasal 10 Undang-UndangNomor 20 Tahun 2008 tentang Usaha Mikro, Kecil, dan Menengah mengenai aspek informasi usaha pada huruf $\mathrm{c}$ menyebutkan bahwa pemerintah memberikan jaminan transparansi dan akses yang sama bagi semua pelaku usaha mikro, kecil, dan menengah atas segala informasi usaha. Artinya, pemerintah maupun pemerintah daerah memiliki kewajiban memberikan informasi secara terbuka bagi pelaku usaha terkait peluang ekonomi daerah. 


\section{E. Kesimpulan}

Kesimpulan yang didapat dalam penelitian ini adalah :

1. Melalui Peraturan Walikota Tanjungpinang Nomor 37 Tahun 2010 Pemerintah Kota Tanjungpinang membuat kebijakan yang menetapkan Batik Gonggong sebagai salah satu pakaian dinas pegawai Pemerintah Kota Tanjungpinang. Hal ini didasari oleh motif Gonggong yang dirasa dapat mewakili kekhasan Kota Tanjungpinang, tanpa membuat kajian yang mendalam dan ketetapan hukum mengenai batik khas Kota Tanjungpinang. Pemerintah Kota Tanjungpinang tidak secara terbuka memberikan peluang yang setara kepada masyarakat Tanjungpinang untuk menuangkan buah fikirnya untuk dijadikan motif wajib untuk seragam pegawai Pemerintah Kota Tanjungpinang ataupun motif khas daerah. Didalam Hak Cipta pencipta motif batik, dapat menimbulkan konsekuensi hak eksklusif/ hak ekonomi bagi penciptanya. Pemerintah Kota Tanjungpinang belum memaknai demokrasi ekonomi yang merupakan amanat dari UndangUndang Dasar Negara Republik Indonesia Tahun 1945 pada Pasal 33 secara penuh. Diawal penelitian, secara rule of reason peneliti menilai pelaksanaan Peraturan Walikota Tanjungpinang Nomor 37 Tahun 2010 seperti belum melaksanakan amanat Undang-Undang Nomor 5 Tahun 1999 tentang Larangan Praktik Monopoli dan Persaingan Usaha Tidak Sehat, khususnya terkait praktik monopoli (Pasal 17) dan penguasaan pasar (Pasal 19). Tetapi, berdasarkan penelitian didapatkan bahwa pada penjelasan mengenai praktik monopoli dan penguasaan pasar dalam Undang-Undang tersebut, berlaku untuk skala nasional, untuk range minimal $50 \%$ pasar nasional. Dalam kajian hukum Batik Gonggong ini, pelaku usaha Batik Gonggong tidak termasuk dalam kategori Pasal ini. Sebab, Batik Gonggong ruang lingkup usahanya baru terkonsentrasi di Provinsi Kepulauan Riau umumnya, Kota Tanjungpinang dan seluruh pegawai Pemerintah Kota Tanjungpinang pada khususnya.

2. Peraturan Walikota Tanjungpinang belum menjalankan amanat Undang-Undang Nomor 5 Tahun 1999 tentang Larangan Paraktik Monopoli dan Persaingan Usaha Tidak Sehat seutuhnya. Kerjasama antara Pemerintah Kota Tanjungpinang dan pelaku usaha Batik Gonggong merupakan kerjasama yang tidak melanggar hukum, tetapi dalam prosesnya, dapat mengakibatkan ketidakadilan bagi pelaku usaha sejenis di Tanjungpinang. Peraturan Walikota Tanjungpinang Nomor 37 Tahun 2010 tentang Pakaian Dinas Pegawai Negeri Sipil dan Non Pegawai Negeri Sipil Di Lingkungan Pemerintah Kota Tanjungpinang 'terkesan' seperti mengarahkan kepada penggunaan suatu produk tertentu. Undang-Undang Nomor 5 Tahun 1999 tentang Larangan Paraktik Monopoli dan Persaingan Usaha Tidak Sehat Pasal 19 menyatakan "Pelaku usaha dilarang melakukan satu atau beberapa kegiatan, baik sendiri maupun bersama pelaku usaha lain, yang dapat mengakibatkan terjadinya praktik monopoli dan atau persaingan usaha tidak sehat." Kegiatan tersebut berupa:

i. Menolak dan atau menghalangi pelaku usaha tertentu untuk melakukan kegiatan usaha yang sama pada pasar bersangkutan. 
ii. Atau mematikan usaha pesaingnya dipasar bersangkutan sehingga dapat mengakibatkan terjadinya praktik monopoli dan atau persaingan usaha tidak sehat.

Penjelasan Undang - Undang tersebut diatas, berlaku untuk skala nasional, untuk range minimal $50 \%$ pasar nasional. Dalam kajian hukum Batik Gonggong ini, pelaku usaha Batik Gonggong tidak termasuk dalam kategori Pasal ini. Sebab, Batik Gonggong ruang lingkup usahanya baru terkonsentrasi di Provinsi Kepulauan Riau umumnya, Kota Tanjungpinang dan seluruh pegawai Pemerintah Kota Tanjungpinang pada khususnya.

Pendekatan hukum rule of reason dalam larangan praktik monopoli dan persaingan usaha tidak sehat, mencakup niat atau perilaku daripada pelaku usaha. Walau tak terjadi sanksi atau penetapan pelanggaran hukum, perbuatan yang tidak merepresentasikan proses keadilan ekonomi untuk seluruh kalangan usaha mikro, kecil dan menengah harus dibenahi dan diperbaiki metode atau sistemnya. Agar adil untuk semua pihak.

3. Kesetaraan perlakuan terhadap para pelaku usaha lain belum diakomodir dalam Peraturan Walikota tersebut. Selain belum menerapkan asas keterbukaan, belum merepresentasikan Pasal 10 Undang-Undang Nomor 20 Tahun 2008 tentang Usaha Mikro, Kecil, dan Menengah mengenai aspek informasi usaha (huruf c) yang menyebutkan bahwa pemerintah memberikan jaminan transparansi dan akses yang sama bagi semua pelaku usaha mikro, kecil, dan menengah atas segala informasi.

Pemerintah Kota Tanjungpinang sebagai pembuat kebijakan belum memaksimalkan peran publik. Dalam kajian hukum mengenai Batik Gonggong ini, dirasa peran publik sangat dibutuhkan. Membuat motif batik wajib untuk pegawai Pemerintah Kota Tanjungpinang seyogyanya mencerminkan motif batik khas daerah. Dimana motif khas daerah didapat dari ide dan buah fikir yang mampu merepresentasikan kekhasan suatu daerah. Hal seperti itu idealnya melibatkan dan diketahui oleh publik, sebagai bahan awal membuat sebuah kajian. Apalagi ditetapkan dalam peraturan perundang-undangan sebuah motif menjadi motif batik daerah. Selain belum menerapkan semangat Undang-Undang Nomor 5 Tahun 1999, Pemerintah Kota Tanjungpinang seharusnya juga mempedomani Pasal 3 Undang-Undang Nomor 28 Tahun 1999 tentang Penyelenggaraan Negara yang Bersih dan Bebas Kolusi, Korupsi dan Nepotisme. Diantara asas umum penyelenggaraan negara, terdapat asas kepentingan umum; asas yang mendahulukan kesejahteraan umum dengan cara yang aspiratif, akomodatif dan selektif dan asas keterbukaan, yang seluruhnya membutuhkan transparansi informasi untuk publik.

Walaupun Peraturan Walikota Tanjungpinang Nomor 37 Tahun 2010 tersebut tidak berlaku lagi dengan terbitnya Peraturan Walikota Tanjungpinang Nomor 13 Tahun 2012 tentang Perubahan atas Peraturan Walikota Nomor 37 Tahun 2010 Tentang Pakaian Dinas Pegawai Negeri Sipil dan Non Pegawai Negeri Sipil Di Lingkungan Pemerintah Kota Tanjungpinang yang tidak mencantumkan kewajiban memakai Batik Gonggong, tapi tidak sertamerta menyelesaikan 
beberapa pertanyaan bagi peneliti. Akhirnya, didapat jawaban dan kesimpulan setelah menyelesaikan penelitian ini.

Dari hasil penelitian yang telah dilaksanakan, dapat dikemukakan beberapa hal yang dapat dijadikan rekomendasi atau saran terkait hal ini, antara lain:

1. Perlunya sosialisasi atau informasi terbuka untuk masyarakat atau pelaku pelaku usaha terkait, apabila kebijakan atau produk hukum pemerintah daerah memiliki dampak memajukan perekonomian pelaku usaha secara menyeluruh atau memiliki konsekuensi ekonomi terhadap publik.

2. Perlunya keterwakilan atau keterlibatan publik yang memahami mengenai produk atau seni khas daerah untuk membuat kajian dalam menentukan suatu motif batik untuk dijadikan produk khas daerah, sebelum menjadi kebijakan atau produk hukum pemerintah daerah.

3. Dilakukan sayembara atau perlombaan terbuka untuk masyarakat atau pelaku - pelaku usaha terkait penentuan motif batik atau kerajinan khas daerah lainnya, agar memenuhi asas keadilan untuk semua pihak yang memiliki keinginan dan kemampuan yang sama. 


\section{DAFTAR PUSTAKA}

\section{Buku}

A.N. Suyanto, 2002, Sejarah Batik Yogyakarta, Merapi, Yogyakarta, hlm. 2. Rasyidi Lili, 1990, Dasar-Dasar Filsafat Hukum, Citra Aditya, Bandung, hlm. 47.

Rahardjo Satjipto, 2010, Ilmu Hukum, Citra Aditya Bakti, Bandung, hlm. 189.

\section{Artikel}

Atmasamita Romli, "Menata kembali masa depan pembangunan hukum nasional", Makalah disampaikan dalam Seminar Pembangunan Hukum Nasional VIII di Denpasar, 14-18 Juli 2003, hlm. 7.

Lawrence W. Friedman, American Law : An invaluable guide to the many of the law, and how it affects our daily lives, W. W Norton \& Company, New York, 1984, hlm. 1-8. Dan pada legal culture and social development, stanford law review, New York, hlm 1002-1010 serta dalam law in America: a Short History, Modern Library Chronicles Book, New York, 2002, hlm. 4-7.

\section{Sumber Internet}

Edyyono Luthfi Widagdo, "Resensi: Integritasi Teori Hukum Pembangunan dan Teori Hukum Progresif", http://luthfiwe. blogspot.com/2012/06/integrasiteori-hukum-pembangunan dan.Html, diakses tanggal 5 Desember 2014.

Atmasasmita Romli, http://www.negarahukum.com/hukum/mengurai-sepintas$\%$ E2\%80\%9Chukum integratif\%E2\%80\%9D-romli-atmasasmita.Html, diakses tanggal 5 Desember 2014.

\section{Peraturan Perundang-undangan}

Undang-Undang Nomor 5 Tahun 1999 tentang Larangan Praktik Monopoli dan Persaingan Usaha Tidak Sehat

Undang-Undang Nomor 20 Tahun 2008 tentang Usaha Mikro, Kecil dan Menengah Peraturan Walikota Nomor 37 Tahun 2010 Tentang Pakaian Dinas Pegawai Negeri Sipil dan Non Pegawai Negeri Sipil di Lingkungan Pemerintah Kota Tanjungpinang 